\title{
Comparison of oral microflora in selective IgA deficiency and $x$ linked agammaglobulinemia cases with control group
}

\author{
Ayça Aslan Kıykım1, Nursen Topçuoğlu², Güven Külekçi2, Haluk Çokuğraş1, Necla Akçakaya1, Yııdız Camcıoğlu1 \\ 1/stanbul University Cerrahpaşa Medical Faculty, Department of Pediatrics, Division of Pediatric Allergy and Immunology, Istanbul, Turkey \\ 2istanbul University, Faculty of Dentistry, Division of Microbiology, Istanbul, Turkey
}

\section{Summary}

Aim: X linked agammaglobulinemia and selective IgA deficiency are predominantly antibody deficiency syndromes. Recurrent sinopulmonary infections are common problems observed in both diseases. IgG, IgM and salivary $\lg A$ which are present especially in gingival crevice are involved in the defense of the oral cavity. The aim of our study was to investigate oral mucosa, dental health and variation in the microflora in selective IgA deficiency and XLA patients by comparison with the healthy group.

Material and Method: We reviewed 18 selective IgA deficient subjects (12 (66.7\%) boys and 6 (33.3\%) girls), 12 patients with Bruton's disease and 31 age-matched healthy children aged 2-18 years with normal leucocyte and immunoglobuline levels. Oral mucosal investigation, dental caries, plaque and gingival indices were assessed and all patients were evaluated for S.mutans, Lactobacillus and yeast colonization in İstanbul University Faculty of Dentistry.

Results: No significant differences were detected between the groups in terms of high MS level and other parameters. Significantly higher lactobacillus and yeast levels were found in XLA patients compared to the selective IgA deficient subjects and healthy group, respectively. High lactobacillus and yeast levels were correlated with frequent consumption of starch-rich food. Presence of dental caries was correlated with high plaque and gingival indices.

Conclusions: The higher frequency of Lactobacillus and yeast colonization in XLA patients indicates that antibodies have a major influence on oral microbiota and antibacterial defense. The similar frequency of dental caries and oral mucosal lesions among the groups suggests the importance of neutrophils and antibacterial substances taking part in innate immunity. (Turk Arch Ped 2013; 48: 204-209)

Key words: Dental caries, selective IgA deficiency, oral microbiota, $\mathrm{X}$ linked agammaglobulinemia

\section{Introduction}

Primary immune deficiencies are characterized with disorders in the immune system function in relation with congenital gene disorders (1). Selective IgA deficiency is the most common primary immune deficiency. In patients with selective IgA deficiency, upper and lower respiratory infections and gastrointestinal infections are observed frequently. The common characteristic is defect in maturation of $B$ cells which release $\lg A(2,3)$. In $\lg A$ deficiency, $B$ cells can synthesize $\lg A$ and carry $\lg M$ and $\lg D$, but are not developed completely and can not transform into plasma cells $(4,5)$. Intrinsic B cell defect and dysfunction of helper and supressor $T$ cells have been reported in IgA deficiency (6). $X$ linked agammaglobulinemia $(X L A)$ is characterized with low serum immunoglobulin levels and lack of mature $B$ lymphocytes and plasma cells in circulation because of pause in the stages of maturation and differentiation of $B$ lymphocytes (7). Sinopulmonary infections are observed frequently in both selective IgA deficiency and XLA.

IgG, IgM and IgA antibodies against intraoral microorganisms have been shown in the serum and gingival crevice and secretory $\lg A$ and $\lg G$ antibodies have been shown in the saliva $(8,9,10,11,12,13)$. Secretory $\lg A$ and IgM are important in the defense of oral microflora. It is thought that absence of one or both may lead to a predisposition to intraoral infections in patients with primary humoral immune deficiencies $(14,15,16)$.

Caries is demineralization of the surface of the tooth by bacteriae. (17). Caries is one of the most common infectious diseases worldwide and is affected by many agents. The primary agent is mutans streptococci (MS=Streptococcus mutans and Streptococcus sobrinus). The secondary

Address for Correspondence: Dr. Ayça Aslan Kıykım,ístanbul University Cerrahpaşa Medical Faculty, Department of Pediatrics, Division of Pediatric Allergy and Immunology, İstanbul, Turkey E-mail: dr gora@yahoo.com Received: 27.12.2012 Accepted: 01.31.2013 
bacteriae in caries include lactobacilli (LB) and yeast. Mutans streptococci and LB are members of the normal oral microflora. These bacteriae are special bacteriae which grow in number with fermentable carbohydrates we consume (especially with saccarose), which rapidly produce acid (acidogenic) by breaking down these carbohydrates and which can survive in acidic environment (18). Caries is a special infectious disease which is also related with many factors including the type of carbohydrates and eating frequency, the resistance of the teeth according to the state of exposure to flouride, the properties of the saliva, general health status, appropriateness of oral care and socioeconomical status in addition to these microorganisms.

Many studies related with oral and dental health have been conducted in patients with immune deficiency $(19,20,21,22,23,24,25)$. In addition to studies in which dental caries and periodontal diseases were found with a higher rate in patients with humoral immune failure $(21,22)$, there are studies in which no significant difference was reported between the patient and healthy control groups $(20,24)$.

In this study, we aimed to evaluate gingival and dental health in patients with selective IgA deficiency and XLA and investigate oral microflora which cause caries.

\section{Material and Method}

Our prospective study was conducted with 30 patients with a diagnosis of primary immune deficiency followed up in Cerrahpaşa Medical Faculty, Department of Pediatrics, Pediatric Immunology and Allergy Outpatient clinic between June 2009 and November 2009 and a control group which consisted of 31 healthy children who presented to our general pediatric outpatient clinic because of any acute health problem (İstanbul University Cerrahpaşa Medical Faculty 2009).

18 patients were included in the group with a diagnosis of selective IgA deficiecny (12 male, 6 female) and 12 male patients were included in the group with a diagnosis of XLA.

Children aged between 2 and 18 years whose leukocyte and immunoglobulin values were within normal ageappropriate limits who presented to the general pediatric outpatient clinic were included in the control group. The children who had more than 8 upper respiratory infections a year, who had more than two severe sinus infections a year, who had a history of ineffective antibiotic use for longer than two months, who had more than two pneumonia attacks a year, who had recurring deep tissue or organ abscesses, who had a history of hospitalization, who had a diagnosis of autoimmune disease, who used immunosuppresive drugs and who had received any blood product were not included in the control group.
Immunological evaluation: Complete blood count and serum immunoglobulin measurements were done in the control group which was constituted of healthy children. 2 $\mathrm{ml}$ peripheral blood was collected in EDTA tubes from each patient. Blood counts were determined using electronic cell counters (Symex xt 2000i).

For measurement of serum immunoglobulin levels $3 \mathrm{ml}$ samples of peripheral blood were collected and their sera were seperated. Immunoglobulin levels were determined as $\mathrm{mg} / \mathrm{dl}$ with nephelometric method using nephelometer device ( Dade Behring, BN II model ) (26). The subjects with $\lg G, \lg A$ and $\lg M$ values -2 standard deviation below the age-appropriate normal value were considered low and were not included in the control group.

$2 \mathrm{ml}$ peripheral blood was collected in EDTA tubes from each patient to determine $B$ lymphocyte values. 20 microliters monoclonal antibody including anti- CD19 and anti- CD20 and 100 microliters blood with EDTA were placed in $5 \mathrm{ml}$-polystyrene tubes (Becton Dickinson, Falcon) and vortexed for 2 seconds. After the sample was incubated in the dark for 15 minutes at room temperature, $2 \mathrm{~mL}$ 'facs lysing' solution was added and the sample was vortexed for 2 seconds. It was incubated for 10 minutes in the dark at room temperature for breaking down of the erythrocytes. Afterwards, it was centrifuged at 250 $\mathrm{q}$ for 5 minutes. The supernatant was removed and the remaining part was vortexed. $3 \mathrm{ml}$ 'cell wash' was added and it was centrifuged for 5 minutes. The supernatant was removed and 500 microliters 'cell wash' was placed in the tube. The prepared sample was placed in a FACScalibur model (Becton Dickinson) device and the numbers of lymphocytes and lymphocyte subgroups (T3, T4, T8, B, NK) were determined as percentages. Btk gene mutation analysis was done using PCR and DNA sequenc analysis in Erasmus MC, University Medical Center Roterdam, Immunology Department.

Oral dental examination: Oral dental examination was perfomed by a single dentist (NT) according to the criteria of the World Health Organization to evaluate the oral and dental health states of the patients. The number of decayed and filled deciduous teeth and the number of decayed, missing and filled permanent teeth (dft/DMFT) were calculated. Values above one or higher were considered as presence of caries. Oral hygiene habits were evaluated in terms of the daily frequency of brushing teeth. G \& V OHI-S Plaque Index and Loe\&Silness Gingival Index were used to evaluate plaque accumulation and gingival health which are indicators of oral care. For both indexes, a score of zero was considered as good oral care and scores of one and above were considered as poor oral care. Nutritional habits related with caries were evaluated by interrogating carbohydrate-rich main meals and the daily frequency of more than three snacks containing starch. For intraoral 
examination of the patients the presence of lesions in the soft tissue was investigated and history of lesion was interrogated.

Microbiological examination: For microbiological examination stimulated saliva samples were collected by letting the patients chew sugar free gum. In patients who could not chew gum, the mouth was rinsed with $5 \mathrm{~mL}$ sterile normal saline and the rinse sample was obtained. In younger children in whom none of these two methods could be used to obtain samples, swab samples from the dental surfaces were obtained using sterile swabs (27).

The samples obtained were cultured directly and by diluting 10-fold in Mitis Salivarius Basitrasin agar (Acumedia Man Inc., Baltimore, Maryland) medium for MS and in Rogosa SL Agar (Merck) medium for LB and incubated with $5-10 \%$ CO2. They were cultured in Sabouraud Dextrose Agar (Merck) medium for yeast and was incubated at $37^{\circ} \mathrm{C}$ for 48 hours. Mutans streptococci, LB and yeast numbers were calculated as cfu/mL. A high level was considered to be $>105 \mathrm{cfu} / \mathrm{mL}$ for $\mathrm{MS},>104 \mathrm{cfu} / \mathrm{mL}$ for LB and $\geq 102 \mathrm{cfu} /$ $\mathrm{mL}$ for yeast $(27,28,29)$.

Statistical Assessment: The data obtained were analysed using SPSS 18.0 statistical program. The categorical data were compared using Pearson's chisquare test. A $p$ value of $<0.05$ was considered statistically significant.

\section{Results}

A total of 18 patients with a diagnosis of selective $\operatorname{lgA}$ ( 12 male and 6 female) and 12 male patients with a diagnosis of XLA were included in the study. The control group consisted of a total of 31 healthy children (17 male and 14 female). The mean age was 8 years and three months \pm 3 years and 6 months in the patients with selective $\lg A$ deficiency, 11 years and 11 months \pm 5 years and 11 months in the patients with XLA and 8 years and 10 months \pm 4 years and 3 months in the control group.

When intraoral examination findings were evaluated, no significant difference was found between the patient and control groups in terms of the frequency of caries, presence and history of intraoral lesion and plaque and gingival index values (Table 1). When the groups were considered together, presence of caries was found in $66 \%(n=29)$ of the children with high plaque index $(n=44)$ and in $71 \%(n=22)$ of the children with high gingival index $(n=31)$. Presence of caries was significantly related with high plaque and gingival index results $(p<0.001$ and $p<0.05$, respectively).

For microbiological examination stimulated saliva samples were collected from 48 of 61 children, swab samples were collected from 6 and oral rinse solution samples were collected from 5 . No sample was obtained from two patients.

High levels of MS, LB and yeast were found in $76 \%$ $(n=45), 54 \%(n=32)$ and $39 \%(n=23)$ of the samples, respectively. Table 1 shows the distribution of these persentages between the groups. When the patients with $X$ linked agammaglobulinemia and IgA deficiency were compared between themselves, it was observed that highlevel LB was found with a significantly higher rate in XLA $(p=0.025)$. When the XLA group and the control group were compared, high level yeast was found with a significantly higher rate in the XLA group ( $p=0.016)$ (Figure 1).

When eating habits were interrogated, it was found that $11 \%(n=2)$ of the patients with IgA deficiency, $25 \%(n=3)$ of the patients with XLA and $29 \%(n=9)$ of the control group were eating carbohydrate-rich diet. When the three groups were compared, no significant difference was found in terms of consuming carbohydrate-rich diet ( $p>0.05)$. 22\% $(n=4)$ of the patients with $\lg A, 50 \%(n=6)$ of the patients with XLA and $19 \%(n=6)$ of the control group were consuming between-meal snacks containing starch. No significant difference was found between the three groups in terms of frequency of starch containing snacks ( $p>0.05)$. When the groups were considered together, the rate of high MS, LB and yeast was found to be $73 \%(n=11), 80 \%(n=12)$ and $73 \%(n=11)$, respectively in the subjects who consumed

Table 1. Comparison of intraoral examination findings and microbiological data in the subjects included in the study

\begin{tabular}{|l|c|c|c|c|}
\hline & $\begin{array}{c}\text { Selective IgA } \\
\text { deficiecny }(\mathbf{n}=\mathbf{1 8})\end{array}$ & $\begin{array}{c}\text { XLA } \\
(\mathbf{n}=\mathbf{1 2})\end{array}$ & $\begin{array}{c}\text { Control group } \\
(\mathbf{n}=\mathbf{3 1})\end{array}$ & $\begin{array}{c}\text { Significance by } \\
\text { Pearson's chi-square test }\end{array}$ \\
\hline Presence of intraoral lesion & $\% 16.7$ & 0 & $\% 9.7$ & $\mathrm{p}=0.324(\mathrm{NS})$ \\
\hline Presence of caries & $\% 55.6$ & $\% 50$ & $\% 51.6$ & $\mathrm{p}=0.948$ (NS) \\
\hline High plaque index & $\% 83.3$ & $\% 75$ & $\% 64.5$ & $\mathrm{p}=0.356(\mathrm{NS})$ \\
\hline High gingival index & $\% 55.6$ & $\% 33.3$ & $\% 54.8$ & $\mathrm{p}=0.401$ (NS) \\
\hline High MS level & $\% 72.2$ & $\% 83.3$ & $\% 76.7$ & $\mathrm{p}=0.780(\mathrm{NS})$ \\
\hline High LB level & $\% 33.3$ & $\% 83.3$ & $\% 76.7$ & $\mathrm{p}=0.071$ (NS) \\
\hline High yeast level & $\% 38.9$ & $\% 66.7$ & $\% 26.7$ & $\mathrm{p}=0.055(\mathrm{AD})$ \\
\hline
\end{tabular}

NS: nonsignificant 


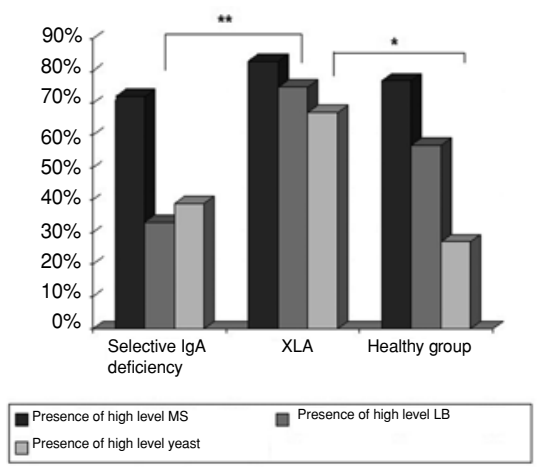

Figure 1. Comparison of the groups in terms of high

starch containing snacks frequently, $78 \%(n=35), 44 \%$ $(n=20)$ and $27 \% \quad(n=12)$, respectively in the subjects who consumed starch-containing snacks infrequently. Accordingly, high lactobacillus and yeast levels were found to be correlated with consuming starch-containing snacks frequently ( $p<0.05$ and $p<0.001$, respectively).

\section{Discussion}

Limited number of studies related with oral health in patients diagnosed with selective IgA deficiency and XLA have shown contradictory results. While Brathall et al. (30) reported increased risk of periodontal disease in patients with hypogammaglobulinemia, Robertson et al. (19) found no significant difference in the healthy group. Robertson et al. (20) found that the frequency of caries and gingivitis was lower in patients with immune deficiency compared to the healthy group in another study. Cole et al. (21) and Legler et al. (22) found that the frequency of caries and S.mutans level were higher in patients with immune deficiency. Brown et al. (23) found the yeast level to be higher in patients with immune deficiency and S.mutans level to be higher in the healthy group. In our study, no significant difference was found between the patients with a dignosis of XLA and selective IgA deficiency and healthy children in terms of dental caries, presence and history of intraoral lesion. The fact that the rates of caries and intraoral lesions and bacteria and yeast levels were not higher in children with IgA deficiency compared to the healthy group has been related with compensatory excessive release of secretory $\operatorname{lgM}(21,31,32,33,34)$. In our study, no significant difference was found in XLA patients who had low serum IgM values, either. This may be partly explained by the fact that neutrophil functions are adequate in these patients.

In our study, no significant difference was found between the three groups in terms of saliva MS, LB and yeast levels. The rate of $L B$ was found to be higher in XLA patients compared to the patients with selective $\lg A$ deficiency. In addition, yeast levels were found to be higher in XLA patients compared to the control group.
Specific and non-specific antimicrobial factors in the oral cavity do not act by themselves; they may act synergistically or antagonistically (35). Arnold et al. (36) found high levels of lysozyme and lactoferrin in individuals with immune system dysfunction. It was shown that the agglunitation action for Streptococcus sanguinis and S.mutans was higher in the saliva originating from the parotid salivary gland in patients with IgA deficiency compared to the control group. This increased action may be related with IgM antibodies or other molecules including parotid salivary agglutinins (37).

Many factors are involved in formation of caries. The variables which may lead to differences between studies performed include factors which may affect the severity of the disease including age, education level, eating habits, oral cleaning, frequency of dental visits and flouride intake. In addition, long-term antibiotic therapies in individuals exposed to recurrent infections and immunoglobulin replacement therapies may supress the microorganisms in the dental plaque $(19,24)$.

Marcotte et al. (38) found no significant difference between mice with agammaglobulinemia and healthy mice in terms of intestinal and intraoral bacterial groups. These results may suggest that immunoglobulins do not play a significant role in the microflorae of mice. The role of secretory lgA may be masked by more predominant bacterial interactions, environmental factors, physiological factors related with the host or other host defense mechanisms. The interactive adaptation process between intra-oral native bacteriae and the host probably starts immediately after delivery. Lack of secretory IgA is compensated by other salivary and mucosal defense factors found in the native immune system of the host $(39,40)$.

In our study, no significant difference was found between the groups in terms of eating carbohydrate-rich main meals and frequent consumption of starch containing snacks. Thus, no nutritional difference which could affect formation of caries and cariogenic bacterial levels was found. Although no nutritional difference was found between the three groups, the LB and yeast levels were found to be higher in individuals who consumed starch-containing snacks frequently, when the groups were considered together. McCourtie et al. (41) showed that frequent consumption of starch-containing products facilitated the yeast to adhere to the oral mucosa. Knight et al. (42) showed that sugar-rich diet could increase the growth of yeast. Therefore, eating habits should be interrogated in all children independent of a diagnosis of immune deficiency and balanced nutrition should be recommended in order to protect the oral health.

In our study, high LB and yeast levels were found to be significantly related with consuming starch-containing snacks frequently and a significant correlation was found between caries and high plaque and gingival indexes. This results showed that patients and healthy children 
had mutual specific factors for formation of caries. This showed that all children included in the study had high risk for caries. No difference was found between the groups in terms of presence and history of lesions in the oral mucosa. Therefore, antibody deficiency was not found to have a negative effect on dental health and the health of oral mucosa.

Pediatricians are conscious of the necessity of examination of all the systems of the patients who are referred to themselves rahter than considering only the complaints. However, a point missed by all of us is oral health. In humoral immune deficiencies where sinopulmonary infections are observed frequently, oral and dental examination should be performed with regular intervals in addition to normal examination. Since antibiotic therapies used in these patients may affect the balance of the oral flora negatively, this should absolutely be considered when starting treatment.

\section{Conflict of interest: None declared.}

\section{References}

1. Bonilla FA, Geha RS. 12. Primary immundeficiency diseases. J Allergy Clin Immunol 2003; 111: S571-581.

2. Cunningham-Rundles $C$. Physiology of $\lg A$ and $\lg A$ deficiency. $J$ Clin Immunol 2001; 21: 303-309

3. Wang Z, Yunis D, Irigoyen M, Kitchens B, Bottaro A, Alt FW, Alper CA. Discordance between IgA switching at the DNA level and IgA expression at the mRNA level in IgA-deficient patients. Clin Immunol 1999; 91: 263-270.

4. Lawton AR, Royal SA, Self KS, Cooper MD. IgA determinants on B-lymphocytes in patients with deficiency of circulating IgA. J Lab Clin Med 1972 ;80: 26-33.

5. Conley ME, Cooper MD. Immature IgA B cells in IgA-deficient patients. N Engl J Med 1981; 305: 495-497.

6. Yel L. Selective IgA deficiency. J Clin Immunol 2010; 30: 10-16.

7. Yalçın I. X'e bağlı agammaglobülinemi (Bruton Hastalığı). Türkiye Klinikleri Pediatrik Bilimler 2005; 1:7-9.

8. Ebersole JL. Humoral immune responses in gingival crevice fluid local and systemic implications. Periodontol 2000 2003; 31: 135166.

9. Ebersole JL, Taubman MA, Smith DJ. Gingival crevicular fluid antibody to oral microorganisms. II. Distribution and specificity of local antibody responses. J Periodontal Res 1985; 20: 349-356.

10. Smith DJ, Houte J, Kent R, Taubman MA. Effect of antibody in gingival crevicular fluid on early colonization of exposed root surfaces by mutans streptococci. Oral Microbiol Immunol 1994; 9 : 65-69.

11. Mouton C, Hammond PG, Slots J, Genco RJ. Serum antibodies to oral Bacteroides asaccharolyticus (Bacteroides gingivalis): relationship to age and periodontal disease. Infect Immun 1981; 31:182-192.

12. Luo Z, Smith DJ, Taubman MA, King WF Cross-sectional analysis of serum antibody to oral streptococcal antigens in children. $J$ Dent Res 1988; 67: 554-560.

13. Kent R, Smith DJ, Joshipura K, Taubman MA. Humoral IgG antibodies to oral microbiota in a population at risk for root-surface caries. J Dent Res 1992; 71: 1399-1407.
14. Atkinson J, O'Connell A, Aframian D. Oral manifestations of primary immunological diseases. J Am Dent Assoc 2000; 131: 345-356.

15. Tar I, Kiss C, Marodi L, Marton IJ. Oral and dental conditions of children with selective IgA deficiency. Pediatr Allergy Immunol 2008; 19: 33-36.

16. Nikfarjam J, Pourpak Z, Shahrabi M, Nikfarjam L, Kouhkan A, Moazeni M, Aghamohammadi A. Oral manifestations in selective IgA deficiency. Int J Dent Hyg 2004; 2: 19-25.

17. Coykendall AL. Proposal to elevate the subspecies of Streptococcus mutans to species status based on their molecular composition. Int J Syst Bacteriol 1977; 27: 26-30.

18. Külekçi G. Bir infeksiyon hastalığı: Diş çürüğü. İçinde: Agacfidan A, Erturan AZ, (yazarlar). XXXIII. Türk Mikrobiyoloji Kongresi Kongre Kitabı. İstanbul, 2008:148-156.

19. Robertson PB, Wright TE, Mackler BF, Lenertz DM, Levy BM. Periodontal status of patients with abnormalities of the immune system. J Periodontal Res 1978; 13: 37-45.

20. Robertson PB, Mackler BF, Wright TE, Levy BM. Periodontal status of patients with abnormalities of the immune system. Part II. Observations over a 2-year period. J Periodontol 1980; 51: 7073.

21. Cole MF, Arnold RR, Rhodes MJ, McGhee JR. Immune dysfunction and dental caries: a preliminary report. J Dent Res 1977; 56: 198204.

22. Legler DW, McGhee JR, Lynch DP, Mestecky JF, Schaefer ME, Carson J, Bradley EL Jr. Immunodeficiency disease and dental caries in man. Arch Oral Biol 1981; 26: 905-910.

23. Brown LR, Mackler BF, Levy BM, Wright TE, Handler SF, Moylan JS, Perkins DH, Keene HJ. Comparison of the plaque microflora in immunodeficient and immunocompetent dental patients. J Dent Res 1979; 58: 2344-2352.

24. Dahlen G, Bjorkander J, Gahnberg L, Slots J, Hanson LA. Periodontal disease and dental caries in relation to primary IgG subclass and other humoral immunodeficiencies. J Clin Periodontol 1993; 20:7-13.

25. Norhagen GE, Engstrom PE, Hammarstrom L, Smith Cl, Nord CE. Oral and intestinal microflora in individuals with different immunoglobulin deficiencies. Eur J Clin Microbiol Infect Dis 1990; 9: 631-633

26. Aksu G, Genel F, Koturoğlu G, Kurugöl Z, Kütükçüler N. Serum immunoglobulin ( $\lg G, \lg M, \lg A)$ and $\lg G$ subclass concentrations in healthy children: a study using nephelometric technique. Turk $J$ Pediatr 2006; 48: 19-24.

27. Külekçi G. Diş çürüğü aktivite testleri nedir? Neden, ne zaman ve nasıl uygulanmalı? IDO Dergi 2001;81:10.

28. Gold OG, Jordan HV, van Haute J. A selective medium for Streptococcus mutans. Arch Oral Biol 1973; 18: 1357-1364.

29. Rogosa M, Mitchell JA, Wiseman RF. A selective medium for the isolation and enumeration of oral and fecal lactobacilli. J Bacteriol 1951; 62: 132-133.

30. Brathall D, Björkander J. Bacteria and oral fluid component: report of the oral condition in hypogammaglobulinaemic patients. In: Lehner T, Cimasoni G, (eds). The borderland between caries and periodontal disease. London: Academic press, 1980:159-173.

31. Arnold RR, Pruitt KM, Cole MF, Adamson JM, McGhee JR. Salivary antibacterial mechanisms in immunodeficiency. In: I. Kleinberg, S. A. Ellison and I. D. Mandel, (eds.). Saliva and dental caries. New York: N.Y. Information Retrieval Inc, 1979: 449-462.

32. Fernandes FRC, Nagao AT, Mayer MPA, Zelante F, CarneiroSampaio MMS. Compensatory levels of salivary $\operatorname{lgM}$ antiStreptococcus mutans antibodies in IgA-deficient patients. J Invest Allergy Clin Immunol 1995; 5: 151-155. 
33. Engstrom GN, Engstrom PE, Hammarstrom L, Smith Cl. Oral conditions in individuals with selective immunoglobulin $A$ deficiency and common variable immunodeficiency. J Periodontol 1992; 63: 984-989.

34. Norhagen G, Engstrom PE, Hammarstrom L, Soder PO, Smith CIE. Immunoglobulin levels in saliva in individuals with selective IgA deficiency: compensatory IgM secretion and its correlation with HLA and susceptibility to infections. J Clin Immunol 1989; 9: 279-286.

35. Kirstila V, Tenovuo J, Ruuskanen O, Nikoskelainen J, Irjala K, Vilja P. Salivary defense factors and oral health in patients with common variable immunodeficiency. J Clin Immunol 1994; 14: 229-236.

36. Arnold RR, Cole MF, Prince S, McGhee JR. Secretory IgM antibodies to Streptococcus mutans in subjects with selective $\lg A$ deficiency. Clin Immunol Immunopathol 1977; 8: 475-486.

37. Malamud D. Influence of salivary proteins on the fate of oral bacteria. In: Mergenhagen SE, Rosan B, (eds.). Molecular basis of oral microbial adhesion. Washington, D.C: American Society for Microbiology 1985: 117-124.
38. Marcotte $\mathrm{H}$, Lavoie MC. Influence of immunoglobulins on the indigenous oral and intestinal microbiota of mice. Infect Immun 1997; 64: 4694-4699.

39. Aguirre A, Testa-Weintraub LA, Banderas JA, Haraszthy GG, Reddy MS, Levine MJ. Sialochemistry: a diagnostic tool. Crit Rev Oral Biol Med 1993; 4: 343-350.

40. Rudney JD. Does variability in salivary protein concentrations influence oral microbial ecology and oral health. Crit Rev Oral Biol Med 1995; 6: 343-367.

41. McCourtie J, Douglas LJ. Relationship between cell surface composition of Candida albicans and adherence to acrylic after growth on different carbon sources. Infection and Immunity 1981; 32: 1234-1241.

42. Knight L, Fletcher J. Growth of Candida albicans in saliva: Stimulation by glucose associated with antibiotics, corticosteroids and diabetes mellitus. J Infect Dis 1971; 123: 371-377. 